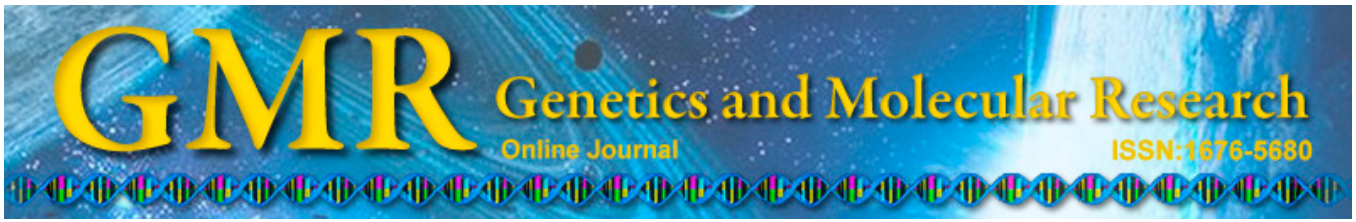

\title{
Development and characterization of novel microsatellite markers in Hyptis pectinata (Lamiaceae)
}

\author{
A.F. Blank ${ }^{1}$, A.S. Jesus ${ }^{1}$, C.P. Santos ${ }^{1}$, C. Grando ${ }^{2}$, J.B. Pinheiro ${ }^{3}$, \\ M.I. Zucchi ${ }^{2}$ and M.F. Arrigoni-Blank ${ }^{1}$ \\ ${ }^{1}$ Programa de Pós-Graduação em Biotecnologia de Recursos Naturais, \\ Universidade Federal de Sergipe, São Cristóvão, SE, Brasil \\ ${ }^{2}$ Laboratório de Biologia Molecular, \\ Agência Paulista de Tecnologia dos Agronegócios, Piracicaba, SP, Brasil \\ ${ }^{3}$ Laboratório de Diversidade Genética e Melhoramento, \\ Departamento Genética e Melhoramento de Plantas, \\ Escola Superior de Agricultura "Luiz de Queiroz", Universidade de São Paulo, \\ Piracicaba, SP, Brasil \\ Corresponding author: A.F. Blank \\ E-mail: afblank@ufs.br
}

Genet. Mol. Res. 13 (4): 10173-10176 (2014)

Received January 2, 2014

Accepted August 10, 2014

Published December 4, 2014

DOI http://dx.doi.org/10.4238/2014.December.4.11

\begin{abstract}
A microsatellite-enriched library was constructed and a set of 19 SSR markers were developed to characterize a germplasm collection of Hyptis pectinata (L.) Poit., maintained at the Universidade Federal de Sergipe (UFS). Fifteen markers of 19 ranged from moderately to highly polymorphic. A total of 113 alleles were identified, with a mean of 7.52 alleles per locus. The mean $H_{\mathrm{O}}$ and $H_{\mathrm{E}}$ were 0.582 and 0.657 , respectively. The primers developed were efficient tools for accessing the genetic diversity of the germplasm collection analyzed and may also be useful for other studies involving this species and other species in the genus Hyptis.
\end{abstract}

Key words: Genetic diversity; Lamiaceae; Molecular markers; Simple sequence repeat 


\section{INTRODUCTION}

Hyptis pectinata (L.) Poit (Lamiaceae) is an important aromatic species commonly known as "sambacaitá" or "canudinho" in the states of Sergipe and Alagoas; it is widely used in folk medicine for the treatment of inflammation and bacterial infections (Arrigoni-Blank et al., 2005). The anti-inflammatory and antinociceptive activities of Hyptis pectinata (L.) essential oil have been confirmed by Raymundo et al. (2011).

Due to the continuous loss of genetic diversity of many genetic resources, such as Hyptis pectinata, a Germplasm Bank of $H$. pectinata was created at the Universidade Federal de Sergipe (UFS); however, there is no information on the genetic variability of this germplasm collection, so far. Microsatellite markers, or simple sequence repeats (SSR), are used for a variety of applications in plant genetics and breeding because they are reproducible, multi-allelic, codominant, relatively abundant, and have good genomic coverage (Remya et al., 2010). In this study, we constructed an enriched genomic library and designed microsatellite primers for $H$. pectinata.

\section{MATERIAL AND METHODS}

Genomic DNA of $H$. pectinata was extracted from the leaf tissues of 56 accessions according to Doyle and Doyle (1990). The plant material collected was immediately stored in liquid nitrogen for lyophilization, ground, and stored at $-20^{\circ} \mathrm{C}$ for DNA extraction.

A microsatellite-enriched genomic library was constructed following the adapted protocol from Billotte et al. (1999). High quality genomic DNA from a single individual of $H$. pectinata was digested with $A f a \mathrm{I}$ (Invitrogen).

The fragments obtained were ligated to Afa21 (5'-CTCTTGCTTACGCGTGGACTA$3^{\prime}$ ) and Afa25 (5'-TAGTCCACGCGTAAGCAAGAGCACA-3') adapters and then amplified via polymerase chain reaction (PCR). Microsatellite-enriched DNA fragments were selected using the $(\mathrm{CT})_{8}$ and $(\mathrm{GT})_{8}$ motifs using magnetic beads connected to streptavidin (Promega). The fragments selected were ligated into the pGEM-T Easy Vector (Promega) and used to transform Epicurian Coli XL1-Blue Escherichia coli competent cells (Promega). The positive clones were selected using the $\beta$-galactosidase gene and then grown overnight with ampicillin. A total of 96 clones were sequenced in an ABI 3770 automated sequencer (Applied Biosystems) using the BigDye Terminator Cycle Sequencing Kit (Applied Biosystems, Foster City, California, USA). The WebSat software (http://wsmartins.net/websat/) was used to identify the microsatellite-containing regions. Twenty-four fragments were identified and contained at least 5 microsatellite motifs. A set of 19 SSR markers were designed using the Primer3 software (http://frodo.wi.mit. edu/primer3/). Subsequently, the primer pairs were synthesized and tested in 56 half-sib accessions from the germplasm collection of the UFS.

The PCR was performed in a final volume of $10 \mu \mathrm{L}$ containing $1.0 \mu \mathrm{L}$ genomic DNA 5.0 ng, $6.65 \mu \mathrm{L}$ ultrapure water, $1.0 \mu \mathrm{L}$ buffer 10X Taq DNA Polymerase [75 mM Tris-HCl; $20 \mathrm{mM}$ $\left(\mathrm{NH}_{4}\right)_{2} \mathrm{SO}_{4}, \mathrm{pH} 8.8 ; 0.01 \%$ (v/v) Tween 20], $0.8 \mu \mathrm{L} \mathrm{MgCl}_{2} 25 \mathrm{mM}, 0.1 \mu \mathrm{L} 2.5 \mathrm{U} / \mu \mathrm{L}$ Taq DNA Polymerase (Fermentas), $0.5 \mu \mathrm{L}$ dNTPs $(2.5 \mathrm{mM}), 0.2 \mu \mathrm{L}$ of each primer (forward + reverse 10 $\mu \mathrm{M}$ ), and $0.1 \mu \mathrm{L}(10 \mu \mathrm{M})$ labeled tag with the fluorophore IRDye700 or IRDye800 (LI-COR Biosciences). The PCR amplification consisted of a touchdown program, an initial cycle at $94^{\circ} \mathrm{C}$ for 5 min; 10 cycles of touchdown at $94^{\circ} \mathrm{C}$ for $40 \mathrm{~s}$ for denaturation, annealing temperature of $-1^{\circ} \mathrm{C}$ for each primer for $40 \mathrm{~s}, 72^{\circ} \mathrm{C}$ for $1 \mathrm{~min}$ for fragments extension; 30 cycles at $94^{\circ} \mathrm{C}$ for $40 \mathrm{~s}, 40^{\circ} \mathrm{C}$ for $40 \mathrm{~s}, 72^{\circ} \mathrm{C}$ for $1 \mathrm{~min}$; and a final extension cycle at $72^{\circ} \mathrm{C}$ for $10 \mathrm{~min}$ and $15^{\circ} \mathrm{C}$ forever. 
The reaction product was electrophoresed on an automated DNA sequencer LI-COR Model 4300 (LI-COR Biosciences) equipped with 2 infrared lasers, with the ability to simultaneously read 2 wavelengths $(700-800 \mathrm{~nm})$ using the standard fragments $(50-350 \mathrm{bp})$ labeled with fluorescence IRDye700 and IRDye800 (LI-COR Biosciences). The exact sizes of the fragments were determined using the SAGA ${ }^{\mathrm{MX}}$ software v3.3 (LI-COR Biosciences). $N_{\mathrm{A}}, H_{\mathrm{O}}$, and $H_{\mathrm{E}}$ were estimated using the Mstools software (Park, 2001). The deviation from Hardy-Weinberg equilibrium and linkage disequilibrium were verified by using the GENEPOP (Rousset, 2008).

\section{RESULTS AND DISCUSSION}

All 19 loci amplified specific bands, with sizes ranging from 140 to $309 \mathrm{bp}$; their sequences were deposited at the National Center for Biotechnology Information (NCBI) and can be accessed using the GenBank accession Nos. provided in Table 1. Fifteen loci exhibited moderate to high levels of polymorphism, varying from 2 to 20 alleles. A total of 113 alleles were identified, with a mean of 7.52 alleles per locus. The $H_{\mathrm{O}}$ and $H_{\mathrm{E}}$ ranged from 0.000 to 1.000 and 0.071 to 0.937 , with means of 0.582 and 0.657 , respectively.

Table 1. Characteristics of 19 microsatellite loci developed for Hyptis pectinata from Sergipe State, northeast Brazil.

\begin{tabular}{|c|c|c|c|c|c|c|c|c|}
\hline $\begin{array}{l}\text { Locus } \\
\text { GenBank No. }\end{array}$ & Primer sequence $\left(5^{\prime}-3^{\prime}\right)$ & Repeat motif & $\mathrm{Ta}\left({ }^{\circ} \mathrm{C}\right)$ & $\begin{array}{l}\text { Size range } \\
\quad(\mathrm{bp})\end{array}$ & $N_{\mathrm{A}}$ & $H_{\mathrm{o}}$ & $H_{\mathrm{E}}$ & $P$ value \\
\hline $\begin{array}{l}\text { Hpe01 } \\
\text { KF781265 }\end{array}$ & $\begin{array}{l}\text { F: *CCTCCATTCACACTCCCCTA } \\
\text { R: GAAACACTCACAGCGAGAGC }\end{array}$ & $(\mathrm{CT})_{16}$ & 50 & 162 & 6 & 0.925 & 0.636 & 0.0000 \\
\hline $\begin{array}{l}\text { Hpe02 } \\
\text { KF781266 }\end{array}$ & $\begin{array}{l}\text { F: *TGAATCCCAATCCGACATC } \\
\text { R: GCGACTGCTCCTACAACTC }\end{array}$ & $(\mathrm{GA})_{15}$ & 50 & $174-208$ & 10 & 0.189 & 0.872 & 0.0000 \\
\hline $\begin{array}{l}\text { Hpe03 } \\
\text { KF781267 }\end{array}$ & $\begin{array}{l}\text { F: *GCTTCATCCCACGGACTA } \\
\text { R: TGTGGGCTGGTGATAGATGT }\end{array}$ & $(\mathrm{CA})_{7}$ & 50 & $228-244$ & 5 & 0.889 & 0.617 & 0.0000 \\
\hline $\begin{array}{l}\text { Hpe04 } \\
\text { KF781268 }\end{array}$ & $\begin{array}{l}\text { F: *TCTCGGATCAACATGAGCTG } \\
\text { R: AGACGTTATTTGGAGCAGCA }\end{array}$ & $(\mathrm{AC})_{11}$ & 50 & $274-284$ & 6 & 0.712 & 0.785 & 0.0000 \\
\hline $\begin{array}{l}\text { Hpe05 } \\
\text { KF781269 }\end{array}$ & $\begin{array}{l}\text { F: *AGCGACTGTTGGGTTTCTC } \\
\text { R: GCACCTCCCTTCTTTCAAC }\end{array}$ & $(\mathrm{TG})_{8}(\mathrm{AT})_{6}$ & 50 & $165-213$ & 20 & 0.830 & 0.937 & 0.0000 \\
\hline $\begin{array}{l}\text { Hpe06 } \\
\text { KF781270 }\end{array}$ & $\begin{array}{l}\text { F: *CACTGCTCCTGCAATCCCAC } \\
\text { R: CCAACTCCAAAGACTTCTAGGC }\end{array}$ & $(\mathrm{CT})_{5}(\mathrm{CA})_{7}$ & 50 & $287-309$ & 11 & 1.000 & 0.830 & 0.0000 \\
\hline $\begin{array}{l}\text { Hpe07 } \\
\text { KF781271 }\end{array}$ & $\begin{array}{l}\text { F: *AGCACAGTTTGGGACTTCA } \\
\text { R: GCTTGTTTTCATCCTCATGC }\end{array}$ & $(\mathrm{AC})_{7}$ & 50 & 193-201 & 4 & 0.982 & 0.556 & 0.0000 \\
\hline $\begin{array}{l}\text { Hpe08 } \\
\text { KF781272 }\end{array}$ & $\begin{array}{l}\text { F: *CAGTTCAGCTCACCCTCCT } \\
\text { R: GCTTTGATCCTGTGTTCCT }\end{array}$ & $(\mathrm{CA})_{7}$ & 50 & $178-192$ & 5 & 0.080 & 0.770 & 0.0000 \\
\hline $\begin{array}{l}\text { Hpe09 } \\
\text { KF781273 }\end{array}$ & $\begin{array}{l}\text { F: *CAAAAATTGATAAGTTCGGTGAA } \\
\text { R: TGTGCAGAATCTCAAACTTCAAA }\end{array}$ & $(\mathrm{GT})_{9}(\mathrm{AG})_{6}$ & 50 & $219-233$ & 6 & 1.000 & 0.680 & 0.0000 \\
\hline $\begin{array}{l}\text { Hpe10 } \\
\text { KF781274 }\end{array}$ & $\begin{array}{l}\text { F: *CAACCTTCCTAACCAAGATATGG } \\
\text { R: AAAGTGACAAGCTCTGCAAGG }\end{array}$ & $(\mathrm{AC})_{8}$ & 50 & 205-211 & 3 & 0.000 & 0.138 & 0.0000 \\
\hline $\begin{array}{l}\text { Hpe11 } \\
\text { KF781275 }\end{array}$ & $\begin{array}{l}\text { F: *GGACTAACCACTTAGGTCTCCAAA } \\
\text { R: ATGGTAGGGTCGTCGGTAGA }\end{array}$ & $(\mathrm{CA})_{7}$ & 50 & $168-170$ & 2 & 0.000 & 0.071 & 0.0000 \\
\hline $\begin{array}{l}\text { Hpe12 } \\
\text { KF781276 }\end{array}$ & $\begin{array}{l}\text { F: *ATGTCTGCTGCCAAATTGC } \\
\text { R: GCCCATTCAATCAACCTACA }\end{array}$ & $(\mathrm{AC})_{8}(\mathrm{ATG})_{4}$ & 50 & $247-275$ & 12 & 0.982 & 0.875 & 0.0090 \\
\hline $\begin{array}{l}\text { Hpe13 } \\
\text { KF781277 }\end{array}$ & $\begin{array}{l}\text { F: *CCCGCTGTTTTTAATAGGTCA } \\
\text { R: CGTGTCTTTTGCTCATTGTTTC }\end{array}$ & $(\mathrm{TG})_{9}$ & 50 & $237-245$ & 3 & 0.113 & 0.414 & 0.0000 \\
\hline $\begin{array}{l}\text { Hpe14 } \\
\text { KF781278 }\end{array}$ & $\begin{array}{l}\text { F: *CGTTGGAAATTCAAGGCTTC } \\
\text { R: GGGATCAAAATGGTCGAGAA }\end{array}$ & $(\mathrm{GAT})_{8}$ & 50 & $268-301$ & 11 & 0.944 & 0.861 & 0.0000 \\
\hline $\begin{array}{l}\text { Hpe15 } \\
\text { KF781279 }\end{array}$ & $\begin{array}{l}\text { F: *CCAATTTATGTTTGCCGTGA } \\
\text { R: GCAGTCATCATGTTTCAAAGC }\end{array}$ & $\mathrm{CA})_{5}(\mathrm{AG})_{30}$ & 50 & $209-243$ & 9 & 0.089 & 0.824 & 0.0000 \\
\hline $\begin{array}{l}\text { Hpe16 } \\
\text { KF781280 }\end{array}$ & $\begin{array}{l}\text { F: *TGCTACTTCATGTCTTGCACA } \\
\text { R: CATTGAGTTTTAGAGGATTGC }\end{array}$ & $(\mathrm{AC})_{6}$ & 50 & 191 & 1 & 0.000 & 0.000 & - \\
\hline $\begin{array}{l}\text { Hpe17 } \\
\text { KF781281 }\end{array}$ & $\begin{array}{l}\text { F: *CAAGAATTTGGTTGGTAGC } \\
\text { R: TCCACGTAAAGTCCCATCT }\end{array}$ & $(\mathrm{CA})_{6}(\mathrm{CATA})_{3}$ & 50 & 140 & 1 & 0.000 & 0.000 & - \\
\hline $\begin{array}{l}\text { Hpe18 } \\
\text { KF781282 }\end{array}$ & $\begin{array}{l}\text { F: *CGAAAGGTGAGGAAGAACA } \\
\text { R: CAAACAAAACCAAGGCATGA }\end{array}$ & $(\mathrm{GT})_{8}$ & 50 & 149 & 1 & 0.000 & 0.000 & - \\
\hline $\begin{array}{l}\text { Hpe } 19 \\
\text { KF781283 }\end{array}$ & $\begin{array}{l}\text { F: *CATGTCTCCAACCCCAACT } \\
\text { R: CGATGTCCAACTCAAGTGG }\end{array}$ & $(\mathrm{CA})_{5}$ & 50 & 231 & 1 & 0.000 & 0.000 & - \\
\hline
\end{tabular}

$\mathrm{Ta}=$ annealing temperature; $\mathrm{P}$ value $=$ probability of deviation from Hardy-Weinberg equilibrium. *M13 tag (5'-CACGACGTTGTAAAACGAC-3') label. 
After Bonferroni's correction, all the loci, except Hpe12, significantly departed from Hardy-Weinberg Equilibrium, which is common for germplasm banks (Sandes et al., 2013). The SSR markers developed were efficient in accessing the high genetic variability present in the germplasm collection of $H$. pectinata maintained at the UFS. The information generated will be useful for the conservation and selection of the most representative genotypes. The microsatellite markers developed may be used for genetic studies in other germplasm banks, population structure analyses, and interspecific genetic studies within the genus Hyptis.

\section{ACKNOWLEDGMENTS}

Research supported by Fundação de Apoio à Pesquisa e à Inovação Tecnológica do Estado de Sergipe (FAPITEC/SE), Conselho Nacional de Desenvolvimento Científico e Tecnológico (CNPq), and Coordenação de Aperfeiçoamento de Pessoal de Nível Superior (CAPES).

\section{REFERENCES}

Arrigoni-Blank AF, Silva-Mann R, Campos DA and Silva PA (2005). Morphological, agronomical and pharmacological characterization of Hyptis pectinata (L.) Poit germplasm. Rev. Bras. Farmacogn. 15: 298-303.

Billotte N, Lagoda PJL, Risterucci AM and Baurens FC (1999). Microsatellite-enriched libraries: applied methodology for the development of SSR markers in tropical crops. Fruits 54: 277-288.

Doyle JJ and Doyle JL (1990). Isolation of plant DNA from fresh tissue. Focus 12: 13-15.

Park S (2001). MStools v3 (Excel Spreadsheet Toolkit for Data Conversion). Smurfit Institute of Genetics, Trinity College, Dublin.

Raymundo LJ, Guilhon CC, Alviano DS, Matheus ME, et al. (2011). Characterisation of the anti-inflammatory and antinociceptive activities of the Hyptis pectinata (L.) Poit essential oil. J. Ethnopharmacol. 134: 725-732.

Remya KS, Joseph S, Lakshmi PK and Akhila S (2010). Microsatellites in varied arenas of research. J. Pharm. Bioallied. Sci. 2: 141-143.

Rousset F (2008). GENEPOP'007: a complete re-implementation of the genepop software for Windows and Linux. Mol. Ecol. Resour. 8: 103-106.

Sandes SS, Pinheiro JB, Zucchi MI, Monteiro M, et al. (2013). Development and characterization of microsatellite primers in Pogostemon cablin (Lamiaceae). Genet. Mol. Res. 12: 2837-2840. 